\title{
Cyclic Cushing's Syndrome: An Overview
}

\begin{abstract}
Cyclic Cushing's syndrome (CS) is a disorder in which glucocorticoid levels are alternately normal and high, the latter occurring in episodes that can last from a few days to several months. It is more common in children than in adults. Cyclic CS may be either of the two different forms of CS (ACTH-dependent or independent CS). Clinically, it may present with one or many symptoms, depending on the duration of disease activity and the timing of the fluctuations. A serotoninergic influence, cyclic changes in central dopaminergic tone, spontaneous episodic hemorrhage in the tumor, and the action of inflammatory cytokines with antitumor properties are some of the mechanisms suggested to explain the physiopathology of this phenomenon but the exact mechanism remains to be clarified. The cyclic pattern of hypercortisolism can delay the final diagnosis of CS and make it difficult to interpret the results of dynamic tests. Patients may have paradoxical responses to dexamethasone that can reflect increasing or decreasing levels of endogenous activity. Hormone assessments have to be repeated periodically when a diagnosis of CS is suspected. The cyclic pattern can also interfere with medical treatment because patients may show unexpected clinical and biochemical signs of hypocortisolism when cortisol secretion cyclically returns to normal, so an accurate follow-up is mandatory in these patients. (Arq Bras Endocrinol Metab 2007;51/8:1253-1260)
\end{abstract}

Keywords: Cyclic Cushing's syndrome; Cortisol; ACTH; Dexamethasone

\section{RESUMO}

\section{Síndrome de Cushing Cíclica: Uma Visão Geral.}

A síndrome de Cushing (SC) cíclica é uma doença na qual os níveis de glicocorticóides são alternadamente normais e elevados, os últimos ocorrendo em episódios que podem durar de poucos dias a vários meses. É mais comum em crianças do que em adultos. SC cíclica pode se manifestar como uma das duas diferentes formas de SC (ACTH-dependente ou independente). Clinicamente, ela pode se apresentar com um ou muitos sintomas, dependendo da duração da atividade da doença e do tempo das flutuações. Influência serotoninérgica, alterações cíclicas no tônus dopaminérgico central, hemorragia tumoral episódica espontânea e ação de citoquinas com propriedades antitumorais são alguns dos mecanismos sugeridos para explicar a fisiopatologia desse fenômeno, mas o mecanismo exato permanece obscuro. O padrão cíclico do hipercortisolismo pode atrasar o diagnóstico final da SC e tornar difícil a interpretação dos resultados dos testes dinâmicos. Alguns pacientes podem ter resposta paradoxal à dexametasona, que pode refletir níveis crescentes ou decrescentes da atividade endógena. A avaliação hormonal precisa ser repetida periodicamente quando há suspeita do diagnóstico de SC cíclica. O padrão cíclico pode também interferir com o tratamento médico, já que pacientes podem apresentar sinais clínicos e bioquímicos inesperados de hipocortisolismo quando a secreção de cortisol retorna ciclicamente ao normal, de modo que um acompanhamento acurado é obrigatório nesses pacientes. (Arq Bras Endocrinol Metab 2007;51/8:1253-1260)

Descritores: Síndrome de Cushing cíclica; Cortisol; ACTH; Dexametasona

\section{revisão}

\author{
Nora Maria ElVIRa Albiger \\ CARLA M. SCARONI \\ Franco MANTERo
}

\author{
Endocrinology Division, \\ Department of Medical and \\ Surgical Sciences, University \\ of Padua, Italy.
}

Recebido em 12/09/07

Aceito em 21/09/07 
T HE MOST COMMON CAUSE of endogenous Cushing's syndrome (CS) is an excessive ACTH secretion by a pituitary adenoma ( $80-85 \%$ of cases $)$. The ectopic secretion of ACTH by non-pituitary tumors accounts for about $10-15 \%$ of cases and, very occasionally, CS may be due to a tumor that secretes corticotropin-releasing hormone $(\mathrm{CRH})$. Adrenocortical adenoma (15-20\%) and, less frequently, adrenal carcinoma or bilateral macro- o micro-nodular hyperplasia (1) are responsible for the ACTH-independent forms of CS.

As demonstrated by Sederberg-Olsen et al. (2), patients with CS (whatever its cause) have episodic cortisol secretion and pituitary-dependent CS seems to be characterized by a more frequent and more severe secretory episodes than ectopic or ACTH-independent forms. The episodic cortisol secretion may, however, be part of a more complex clinical picture involving cyclic or periodic forms of CS that may pose unusual diagnostic problems.

Cyclic CS is a disorder in which rhythmic fluctuations in ACTH secretion result in a more or less predictable cyclic variation in adrenal steroid production. It occurs in a small subset of CS patients and coincides with highly variable levels of glucocorticoid secretion, alternating more or less regularly between normal and high values, following a clinical course of intermittent, cyclic or periodic symptoms of hypercortisolism. Though it is uncommon, cyclic CS is seen more in children than in adults (3-5).

Due to the frequently varying in cortisol secretion levels and the potentially cyclic or periodic hypercortisolism, hormone assessment is recommended on at least two, preferably three separate days when a diagnosis of CS is suspected.

Clinically, cyclic CS may present with one or many symptoms, depending on the duration of the disease activity and the timing of the fluctuations that can vary from a few days to several months $(6,7)$. The results of dynamic tests for diagnosing CS are easier to interpret during a sustained period of hypercortisolism, whereas they may prove difficult during cyclic episodes because paradoxical responses to dexamethasone may reflect an increasing or decreasing endogenous activity instead of the action of the agent administered $(8,9)$. The physiopathology of this condition remains to be clarified, though several possible mechanisms have been proposed.

Normal cortisol secretion between cycles may complicate medical therapy because patients may show unexpected clinical and biochemical signs of hypocortisolism.

\section{CAUSES AND LIKELY MECHANISMS IMPLICATED IN THE PHYSIOPATHOLOGY OF CYCLIC CS}

A cyclic behavior may be a feature of different forms of CS (ACTH-dependent or -independent CS). The most frequent causes of cyclic CS are associated with ACTH-secreting pituitary adenoma (6-9), but it has also been reported in association with a well-differentiated neuroendocrine tumor (typical bronchial carcinoid) and malignant carcinoid tumor of the lung $(10,11)$, oncocytic carcinoid of the kidney (12), bronchial adenoma (13), ectopic ACTH secretion by a pheochromocytoma (14), adrenal adenoma (15) and rare forms of the pigmented variant of micronodular adrenocortical hyperplasia (primary pigmented nodular adrenocortical disease, or PPNAD) $(3,4,16)$. This rare type of CS generally occurs as part of the Carney complex: a cyclic cortisol secretion has been described in $14 \%$ of such patients, characterized by periods of clinical symptoms due to hypercortisolism followed by periods of normal cortisol secretion and normal clinical signs $(3,17)$. The length of these periods varies considerably, ranging from weeks to months.

Data suggesting a hypothalamic origin of cyclic CS come from Beckers et al. (18), who described a patient with intermittent CS following a cortisol hyperpulsatile pattern, who had a sustained response to sodium valproate treatment. Sodium valproate is known to cause an increase in gamma amino-butyric-acid (GABA), which in turn inhibits $\mathrm{CRH}$ secretion. Watanobe et al. (19) suggested that rhythmic fluctuations in ACTH secretion may also be due to a cyclic change in central dopaminergic tone, which is partially responsible for triggering periodic ACTH secretion.

Another explanation put forward is that spontaneous, episodic hemorrhages occur in the tumor, resulting in temporary damage to actively secreting cells (20), or the synchronous growth and death of ACTH-secreting tumor cells. Moreover, pituitary apoplexy can induce a remission of CS $(21,22)$, so a careful follow-up is mandatory in these patients to establish the real course of the disease.

Jordan et al. (23) said that a serotoninergic influence may somehow be involved in the pathogenesis of cyclic CS, since urinary free cortisol (UFC) was greatly reduced in their case and the cyclic secretion was contained by administering a serotonin antagonist. This hypothesis needs to be confirmed, however, because such a response could 
be part of the intrinsic decrease in UFC in the case described.

An unusual combination of Cushing's disease and corticosteroid-binding globulin (CBG) deficiency was described in a patient with periodic ACTH and cortisol secretion (24). Biochemical assessment revealed high plasma free cortisol levels with low CBG concentrations, indicating that it may be useful to measure free cortisol in all such particular cases.

Arnaldi et al. (10) described a patient with a bronchial carcinoid presenting with cyclic CS, initially referred to a neurosurgical unit with suspected Cushing's disease based on indirect signs of a pituitary lesion on MRI (gland asymmetry and minimal stalk deviation). The patient had in vivo ACTH hyperresponsiveness to hexarelin with the simultaneous presence of ghrelin, and both types of receptor (la and $1 \mathrm{~b}$ ) were detected in tumoral, but not peritumoral lung tissue. After surgical removal of the tumor, the ACTH response to ghrelin disappeared. These data suggest an autocrine/paracrine modulatory effect of ghrelin on bronchial ACTH-secreting tumors.

Peri et al. (25) described a patient with an ectopic CS with a cyclic pattern of hypercortisolism and an intriguing dramatic, but temporary drop in ACTH and cortisol levels during a lung infection occurring in a period of overt hypercortisolism. It is well known that states of hypercortisolism may be complicated by opportunist infections (26) and, in cases of endogenous hypercortisolism, the likelihood of bacterial or opportunist infections is highest in patients with markedly high ACTH and cortisol levels, as in ectopic ACTH secretion (27), but the mechanism behind the drop in cortisol levels during the infection remains unexplained. The Authors suggested that the inflammatory process may have caused a temporary remission due to the action of inflammatory cytokines with antitumor properties, such as tumor necrosis factor (TNF) alpha (28).

\section{CLINICAL PRESENTATION}

A strong suspicion is required for the diagnosis of periodic cortisol secretion because patients may present with signs and symptoms of CS but normal cortisol values, which may mislead the final diagnosis. A cyclic CS may be suspected, moreover, in patients with fluctuating cortisol values, anomalous reactions to dexamethasone or an anomalous response to medical treatment.
Clinical presentations can vary from a single, outstanding symptom, such as recurrent edema, to a complex clinical syndrome. The cycles can also vary, lasting from a few hours to 85 days (6), sometimes with long disease-free intervals (25). Evaluation during such intervals may indicate a normal pituitary function, so the syndrome may be suspected particularly in patients with signs of CS but normal cortisol levels, or with conflicting patterns of response to dexamethasone administration. Paradoxical cortisol responses to the dexamethasone suppression test have been reported by several authors $(8,9)$. Patients usually present with episodes of biochemical and clinical remission alternating with periods of frank Cushing's disease, characterized by circadian hyperpulsatile ACTH and cortisol secretion. Fluctuations in cortisol secretion by tumors have been studied in depth and explain this paradoxical cortisol response to the dexamethasone suppression test.

We described a patient with cyclic CS due to ACTH secretion of suspected ectopic origin complicated by severe mitral valve insufficiency and an increased bleeding risk due to a lack of high-molecular-weight von Willebrand factor multimers (29). This last condition was thought likely to be associated with the valve defect (30). This patient's biochemical data suggested an ectopic origin of the ACTH secretion, but POMC levels were normal, and CT and total body scintigraphy with ${ }^{111}$ In pentreotide and PET images were negative. Inferior petrosal sinus catheterization could not be performed at initial diagnosis because of the high bleeding risk due to the hemostatic anomalies. This case demonstrates that Cushing's syndrome is difficult to diagnose, that there is currently no single biochemical or imaging method offering an optimal accuracy, and that the association of CS with other pathologies may complicate the final diagnosis.

Calvo Romero et al. (31) described a patient with four irregular, symptomatic cycles of hypercortisolism before ketoconazole therapy. This patient had a pituitary MRI with an empty sella. The diagnosis of corticotroph adenoma was established by bilateral petrosal sinus sampling after CRH administration and the patient was successfully treated with hypophysectomy. An empty sella is a neuro-anatomical condition common in middle-aged, obese, multiparous females. It usually occurs with headache and visual disorders, and most patients have a normal pituitary function, but Cushing's disease may be present in $2 \%$ of cases of primary empty sella $(32,33)$. 


\section{WHY CAN PERIODIC CORTISOL PRODUCTION COMPLICATE THE DIAGNOSIS OF CS?}

The diagnosis of CS is based on first-line screening tests that include measuring 24-hour urinary free cortisol (UFC), a low-dose dexamethasone suppression test (DST) and late-night salivary cortisol assay. Second-line screening tests include plasma cortisol circadian rhythm with midnight plasma cortisol assay, lowdose (DST) and DST combined with the CRH test (34). If CS is confirmed, its cause will be classified initially by measuring plasma ACTH levels. If ACTH is suppressed, an adrenal CT or MRI can identify an adrenal lesion responsible for the hypercortisolism. If ACTH is not suppressed, a pituitary or ectopic form will be investigated. ACTH levels tend to be higher in ectopic ACTH-secreting CS than in the pituitary forms, albeit with a considerable overlap.

High doses of dexamethasone administrated overnight or in two days partially suppress ACTH secretion from most corticotroph adenomas, whereas ectopic tumors are resistant to feedback inhibition. In adrenal CS, cortisol secretion is autonomous so there is a lack of cortisol suppression after high-dose glucocorticoids.

Most pituitary tumors causing CS respond to $\mathrm{CRH}$ and desmopressin (DDAVP) stimulation tests, but there may be a significant overlap in the responses between patients with Cushing's disease and ectopic ACTH secretion, particularly when a DDAVP test is performed (35).

Clinicians are often obliged to hospitalize patients several times before obtaining unequivocal biological evidence of cortisol excess. Measuring salivary cortisol is an accurate method for assessing plasma free cortisol and a useful tool in the diagnosis of CS (36). There is also a strong correlation between free plasma and salivary cortisol concentrations (37). Saliva sampling is simple, noninvasive and can easily be done in an outpatient setting. Repeated outpatient midnight salivary cortisol sampling is a highly-effective option for patients with cyclic CS too.

Imaging needs are guided by biochemical assessments. MRI is the method of choice for Cushing's disease, but a pituitary adenoma is normally seen in no more than $36-78 \%$ of patients with Cushing's disease (38-41).

Scintigraphy with radionucleotide-labeled agonists for receptors commonly expressed by neuroendocrine tumors is used to seek occult ACTH-dependent disease (42), sometimes with disappointing results.
Despite improvements in these non-invasive tests, inferior petrosal or cavernous sinus sampling (IPSS or ICSS) is frequently required to differentiate between pituitary and ectopic ACTH production. False negatives have been described using IPSS, however, and many patients thought to have ectopic tumors on the strength of a negative IPSS result remain without a definitive diagnosis (43).

In most cases, the diagnosis of ACTH-independent CS is more straightforward because an adrenal lesion is usually visible, but difficulties can arise not only in the differential diagnosis of adrenal adenomas and carcinomas, but also with the rare forms of sporadic PPNAD, in which patients may have a normal adrenal morphology (44).

The presence of cyclic hormonogenesis may further complicate the final diagnosis. Liberman et al. (9) demonstrated the periodic nature of cortisol steroid production in a patient with CS due to a pituitary adenoma who presented with cycles occurring every 85.8 days. The periodicity was associated with hypercortisolism alternating with biochemical remission and paradoxical cortisol response to dexamethasone, which may be the expression of the periodic hormonogenesis, but it is also seen in patients with CS due to PPNAD during a Liddle test - a phenomenon accompanied by an increased expression of the glucocorticoid receptor in PPNAD nodules (45).

Brown et al. (8) described a patient with CS due to a pituitary adenoma, who presented a paradoxical increase in cortisol after dexamethasone administration: they showed that plasma cortisol levels rose before the first dose of dexamethasone was administered, demonstrating cyclic increases and decreases in steroidogenesis. Theirs was the first accurate description of the apparently paradoxical response to dexamethasone being a purely fortuitous circumstance in a patient with a spontaneously rhythmic steroid production controlled by a mechanism not susceptible to the negative feedback action of steroids. These findings were confirmed and expanded by Atkinson et al. $(46,47)$, who described a patient with cyclic CS due to a pituitary adenoma whose cortisol secretion followed two different rhythms, i.e. a 40-day period of cortisol excess was followed by 60-70 days of normal cortisol secretion; during the period of excess of cortisol production, cortisol secretion peaked every 3-6 days, with intervening troughs of normal cortisol levels.

The cyclic pattern of hypercortisolism demonstrated by the clinical and biochemical remission is variable and, though it is unusual, long-term remission may occur before recurrence (25), particularly in ectopic CS. 


\section{THERAPY}

In terms of the approach to their treatment, patients with cyclic CS do not differ from those with nonintermittent CS, but it is important to bear in mind that it is not uncommon for the former to experience phases of relative adrenocortical insufficiency when medical therapy is initiated, so an accurate follow-up is needed during treatment to avoid this complication.

Moreover, in patients with cyclic CS, the risk of variations in steroidogenesis and the possibility of episodes of hypocortisolism may make the results of drug studies and surgery misleading, which must be considered with caution.

The goals of treatment for patients with hypercortisolism due to ACTH-secreting adenomas include normalizing plasma ACTH and serum cortisol values, shrinking the tumor and preserving pituitary anterior function. Pituitary neurosurgery is the first-line treatment for ACTH-secreting pituitary adenomas. Experienced surgeons achieve an initial biochemical remission in $70-80 \%$ of cases, but a significant number of recurrences are seen during long-term follow-up, the rate ranging between $9 \%$ and $23 \%(48,49)$. Pituitary radiation is reserved for patients failing to respond to surgery, but this treatment may only be effective after several years and it causes a high rate of pituitary insufficiency (50).

Although significant advances have been made in the medical management of CS, the challenge remains to find drugs acting on the etiology of the different forms of the disease.

Currently-available drugs that inhibit steroidogenesis, e.g. mitotane, metyrapone, aminoglutethimide, and ketoconazole, can correct hypercortisolism, quickly normalizing the mean daily plasma cortisol levels in $75 \%$ of patients with CS but they have little impact on tumor growth and can induce hepatotoxicity $(51,52)$.

The competitive glucocorticoid antagonist mifepristone (RU-486) has been recommended for the treatment of patients with CS. It can lead to a symptomatic improvement but only small series have been evaluated so far $(53,54)$.

Successful medical treatment would mean having drugs capable of treating the etiology of CS. Following numerous studies demonstrating which substances are involved in regulating the hypothalamopituitary axis, increasing $\mathrm{CRH}$ and ACTH release, neuromodulator drugs have been proposed to treat the pituitary forms of CS. Serotonin agonists (cypro- heptadine, ketanserin, and retanserin), and also GABA agonists such as sodium valproate $(55,56)$ have been studied, but they have rarely shown real clinical efficacy when used alone and their long-term utility appears to be limited.

The presence of dopamine receptors (D2 subtype) in prolactin-secreting pituitary adenomas has led to dopamine agonists finding a major therapeutic application in the treatment of these tumors, since they are effective in suppressing PRL secretion and inducing tumor shrinkage (57). Treatment with bromocriptine has been investigated in ACTH-secreting or corticotroph pituitary tumors, but with controversial results $(57,58)$. Pivonello et al. (59) recently showed functional D2 receptor expression in corticotroph pituitary tumors and demonstrated that the in vivo effect of cabergoline on the inhibition of cortisol secretion depends on D2 receptor expression on the tumor.

In recent years, new prospects for treating pituitary adenomas have emerged from studies on PPAR $\gamma$ expression and the effect of PPAR $\gamma$ ligands on hormone secretion and cell proliferation, but clinical data have produced controversial results $(60,61)$.

Octapeptide somatostatin analogs proved to be potent inhibitors of ACTH secretion in patients with Nelson's syndrome (62) and in patients with neuroendocrine tumors (63). However, no suppressive effect of octreotide was demonstrated in patients with Cushing's disease. Octreotide and lanreotide bind preferentially to somatostatin receptor-2 (SSTR-2) and the results obtained in patients with Cushing's disease might be explained by somatostatin receptor down regulation by hypercortisolemia (64). SOM230 is a novel somatostatin analog with a high affinity for binding to human SSTR 1, 2, 3, and 5 (65) and, because of its broader binding profile, it is likely to be clinically useful in treating tumors resistant to SSTR2 preferential analogs.

Somatostatin receptor-specific analogs (BIM23190 and BIM-23268) and chimeric analogs which bind both somatostatin and dopamine D2 receptors such as BIM-23A760 and BIM-23A781, have been studied particularly in cell cultures from human GHsecreting pituitary adenomas $(66,67)$, but their efficacy in corticotrophin tumor cells remains to be elucidated.

Lastly, the identification of ectopic or abnormal hormone receptors in adrenal cortisol-secreting nodular hyperplasias has given rise to new opportunities to use specific pharmacological therapies (68-70). 


\section{CONCLUSION}

Cyclic CS poses unusual diagnostic problems. The syndrome should be suspected in patients with symptoms or signs of CS but normal cortisol levels, or with fluctuating cortisol values, or anomalous responses to dexamethasone. Between cycles, patients may have a normal pituitary function, so dynamic test findings are best interpreted if the tests are conducted during a sustained period of hypercortisolism. Confusing results of standard $2 \mathrm{mg}$ and $8 \mathrm{mg}$ dexamethasone suppression tests suggest a spontaneous fluctuation in adrenal secretion that needs to be confirmed by extended periods of observation.

Given the possible variations in steroidogenesis, the clinical and biochemical response to medical treatment and the results of drug studies and surgery in cyclic CS must be interpreted with caution.

\section{REFERENCES}

1. Bertagna X, Raux-Demay MC, Giulhaume B, Girard F, Luton JP. Cushing's disease. In: Melmed S, ed. The pituitary. $2^{\text {nd }}$ ed. Malden: Blackwell, 2002. pp. 592-612.

2. Sederberg-Olsen $P$, Binder $C$, Kehlet $H$, Neville AM, Nielsen LM. Episodic variation in plasma corticosteroids in subjects with Cushing's syndrome of differing etiology. J Clin Endocrinol Metab 1973;36:906-10.

3. Gomez Muguruza MT, Chrousos GP. Periodic Cushing syndrome in a short boy: usefulness of the ovine corticotropin releasing hormone test. J Pediatr 1989;115:270-3.

4. Carson DJ, Sloan JM, Cleland J, Russell CF, Atkinson AB, Sheridan B. Cyclical Cushing's syndrome presenting as short stature in a boy with recurrent atrial myxomas and freckled skin pigmentation. Clin Endocrinol (Oxf) 1988;28:173-80.

5. Gunther DF, Bourdeau I, Matyakhina L, Cassarino D, Kleiner DE, Griffin K, et al. Cyclical Cushing's Syndrome presenting in infancy: an early form of primary pigmented nodular adrenocortical disease, or a new entity? J Clin Endocrinol Metab 2004;89:3173-82.

6. Shapiro MS, Shenkman L. Variable hormonogenesis in Cushing's syndrome. Q J Med 1991;79:351-63.

7. Bailey RE. Periodic hormonogenesis: a new phenomenon. Periodicity in function of a hormone-producing tumor in man. J Clin Endocrinol Metab 1971;32:317-27.

8. Brown RD, Van Loon GR, Orth DN, Liddle GW. Cushing's disease with periodic hormonogenesis: one explanation for paradoxical response to dexamethasone. J Clin Endocrinol Metab 1973;36:445-51.

9. Liberman B, Wajchenberg BL, Tambascia MA, Mesquita $\mathrm{CH}$. Periodic remission in Cushing's disease with paradoxical dexamethasone response: an expression of periodic hormonogenesis. J Clin Endocrinol Metab 1976;43:913-8.

10. Arnaldi G, Mancini T, Kola B, Appolloni G, Freddi S, Concettoni $C$, et al. Cyclical Cushing's syndrome in a patient with a bronchial neuroendocrine tumor (typical carcinoid) expressing ghrelin and growth hormone secretagogue receptors. J Clin Endocrinol Metab 2003;88:5834-40.

11. Chajek T, Romanoff $H$. Cushing syndrome with cyclical edema and periodic secretion of corticosteroids. Arch Intern Med 1976;136:441-3.

12. Hannah J, Lippe B, Lai-Goldman M, Bhuta S. Oncocytic carcinoid of the kidney associated with periodic Cushing's syndrome. Cancer 1988;61:2136-40.
13. Shapiro MS, Gutman A, Bruderman I, Myers B, Griffel WB. Cushing's syndrome associated with a bronchial adenoma. Possible periodic hormonogenesis. Isr J Med Sci 1975; 11:919-4.

14. Terzolo M, Ali A, Pia A, Bollito E, Reimondo G, Paccotti P, et al. Cyclic Cushing's syndrome due to ectopic ACTH secretion by an adrenal pheochromocytoma. J Endocrinol Invest 1994; $17: 869-74$

15. Blau N, Miller WE, Miller ER Jr, Cervi-Skinner SJ. Spontaneous remission of Cushing's syndrome in a patient with an adrenal adenoma. J Clin Endocrinol Metab 1975; 40:659-63.

16. Oelkers W, Bahr V, Hensen J, Pickartz H. Primary adrenocortical micronodular adenomatosis causing Cushing's syndrome. Effects of ketoconazole on steroid production and in vitro performance of adrenal cells. Acta Endocrinol (Copenh) 1986;113:370-7.

17. Sarlis NJ, Chrousos GP, Doppman JL, Carney JA, Stratakis CA. Primary pigmented nodular adrenocortical disease: reevaluation of a patient with Carney complex 27 years after unilateral adrenalectomy. J Clin Endocrinol Metab 1997; 82:1274-8.

18. Beckers A, Stevenaert A, Pirens G, Flandroy P, Sulon J, Hennen G. Cyclical Cushing's disease and its successful control under sodium valproate. J Endocrinol Invest 1990; 13:923-9.

19. Watanobe $H$, Aoki $R$, Takebe K, Nakazono M, Kudo M. In vivo and in vitro studies in a patient with cyclical Cushing's disease showing some responsiveness to bromocriptine. Horm Res 1991;36:227-34.

20. Thorner MO, Martin WH, Ragan GE, MacLeod RM, Feldman PS, Bruni C, et al. A case of ectopic ACTH syndrome: diagnostic difficulties caused by intermittent hormone secretion. Acta Endocrinol (Copenh) 1982;99:364-70.

21. Dikstein G, Spindel A, Schechner C, Adawi F, Gutman H. Spontaneous remission in Cushing's disease. Arch Intern Med 1991;151:185-9.

22. Pignatta $A B$, Días AG, Gómez RM, Bruno OD. Spontaneous remission of Cushing's disease after disappearance of a microadenoma attached to the pituitary stalk. Pituitary 2004;7:45-9.

23. Jordan RM, Ramos-Gabatin A, Kendall JW, Gaudette D, Walls RC. Dynamics of adrenocorticotropin (ACTH) secretion in cyclic Cushing's syndrome: evidence for more than one abnormal ACTH biorhythm. J Clin Endocrinol Metab 1982;55:531-7.

24. Watanobe H, Nigawara T, Nasushita R, Sasaki S, Takebe K. A case of cyclical Cushing's disease associated with corticosteroid-binding globulin deficiency: a rare pitfall in the diagnosis of Cushing's disease. Eur J Endocrinol 1995; 133:317-9.

25. Peri A, Bemporad D, Parenti G, Luciani P, Serio M, Mannelli M. Cushing's syndrome due to intermittent ectopic ACTH production showing a temporary remission during a pulmonary infection. Eur J Endocrinol 2001;145:605-11.

26. Aucott JN. Glucocorticoids and infection. Endocrinol Metab Clin North Am 1994;23:655-70.

27. Sarlis NJ, Chanock S, Nieman L. Cortisolemic indices predict severe infections in Cushing syndrome due to ectopic production of adrenocorticotropin. J Clin Endocrinol Metab 2000;85:42-7.

28. Wallach D, Boldin M, Varfolomeev E, Benyaert R, Vandenabeele $P$, Fiers $W$. Cell death induction by receptors of the TNF family: towards a molecular understanding. FEBS Letters 1997;410:96-106.

29. Mantero F, Scaroni CM, Albiger NM. Cyclic Cushing's syndrome: an overview. Pituitary 2004;7:203-7.

30. Vincentelli A, Susen S, Le Tourneau T, Six I, Fabre O, Juthier $\mathrm{F}$, et al. Acquired von Willebrand syndrome in aortic stenosis. N Engl J Med 2003;349:343-9.

31. Calvo-Romero JM, Morales-Pérez F, Díaz Pérez J. Cyclic Cushing's disease associated with primary empty sella. Eur J Int Med 2000;1:168-70. 
32. Gallardo E, Schachter D, Caberes E, Becker P, Colin E, Martinez C, et al. The empty sella: results of treatment in 76 successive cases and high frequency of endocrine and neurological disturbances. Clin Endocrinol (Oxf) 1992; 37:529-33.

33. Manavela MP, Goodall CM, Katz SB, Moncet D, Bruno OD. The association of Cushing's disease and primary empty sella turcica. Pituitary 2001;4:145-51.

34. Arnaldi G, Angeli A, Atkinson AB, Bertagna $X$, Cavagnini $F$, Chrousos GP, et al. Diagnosis and complications of Cushing's syndrome: a consensus statement. J Clin Endocrinol Metab 2003:88:5593-602.

35. Tsagarakis S, Tsigos C, Vasiliou V, Tsiotra P, Kaskarelis J, Sotiropoulou C, et al. The desmopressin and combined CRHdesmopressin tests in the differential diagnosis of ACTHdependent Cushing's syndrome: constraints imposed by the expression of V2 vasopressin receptors in tumors with ectopic secretion. J Clin Endocrinol Metab 2002; 87:1646-53.

36. Yaneva M, Mosnier-Pudar H, Dugué MA, Grabar S, Fulla $Y$, Bertagna $X$. Midnight salivary cortisol for the initial diagnosis of Cushing's syndrome of various causes. J Clin Endocrinol Metab 2004;89:3345-51.

37. Vining RF, McGinley RA, Maksvytis JJ, Ho KY. Salivary cortisol-a better measure of adrenal cortical function than serum cortisol. Ann Clin Biochem 1983;20:329-35.

38. Invitti C, Pecori Giraldi F, De Martin M, Cavagnini F. Diagnosis and management of Cushing's syndrome: results of an Italian multicentre study. Study Group of the Italian Society of Endocrinology on the Pathophysiology of the Hypothalamic-Pituitary-Adrenal Axis. J Clin Endocrinol Metab 1999;84:440-8.

39. Tabarin A, Laurent F, Catargi B, Olivier-Puel F, Lescene R, Berge $\mathrm{J}$, et al. Comparative evaluation of conventional and dynamic magnetic resonance imaging of the pituitary gland for the diagnosis of Cushing's disease. Clin Endocrinol (Oxf) 1998;3:285-6.

40. Kaskarelis IS, Tsatalou EG, Benakis SV, Malagari K, Komninos I, Vasiliadou D, et al. Bilateral inferior petrosal sinuses sampling in the routine investigation of Cushing's syndrome: a comparison with MRI. Am J Roentgenol 2006; 2:562-3.

41. Barrou Z, Abecassis JP, Guilhaume B, Thomopoulos P, Bertagna $X$, Derome $P$, et al. Magnetic resonance imaging in Cushing disease. Prediction of surgical results. Presse Med 1997;26:7-11.

42. Granberg D, Sundin A, Janson ET, Oberg K, Skogseid B, Westlin JE. Octreoscan in patients with bronchial carcinoid tumours. Clin Endocrinol (Oxf) 2003;59:793-9.

43. Swearingen B, Katznelson L, Miller K, Grinspoon S, Waltman A, Dorer DJ, et al. Diagnostic errors after inferior petrosal sinus sampling. J Clin Endocrinol Metab 2004; 89:3752-63.

44. Stratakis CA, Sarlis N, Kirschner LS, Carney JA, Doppman JL, Nieman LK, et al. Paradoxical response to dexamethasone in the diagnosis of primary pigmented nodular adrenocortical disease. Ann Intern Med 1999;131:585-91.

45. Bordeau I, Lacroix A, Schurch W, Caron P, Antakly T, Stratakis CA. Primary pigmented nodular adrenocortical disease: paradoxical responses of cortisol secretion to dexamethasone occur in vitro and are associated with increased expression of the glucocorticoid receptor. J Clin Endocrinol Metab 2003;88:3931-7.

46. Atkinson AB, Chestnutt $A$, Crothers E, Woods R, Weaver JA, Kennedy $L$, et al. Cyclical Cushing's disease: two distinct rhythms in a patient with a basophil adenoma. J Clin Endocrinol Metab 1985;60:328-32.

47. Atkinson $A B$, Kennedy $A L$, Carson DJ, Hadden DR, Weaver JA, Sheridan B. Five cases of cyclical Cushing's syndrome. Br Med J (Clin Res Ed) 1985;291:1453-7.

48. Barbetta L, Dall'Asta C, Tomei G, Locatelli M, Giovanelli M, Ambrosi B. Assessment of cure and recurrence after pituitary surgery for Cushing's disease. Acta Neurochirurgia (Wien) 2001; 143:477-81.
49. Rees DA, Hanna FW, Davies JS, Miles RG, Vafidis J, Scanlon MF. Long-term follow-up results of transphenoidal surgery for Cushing's disease in a single center using strict criteria for remission. Clin Endocrinol 2002;56:541-51.

50. Estrada J, Boronat M, Mielgo M, Magallon R, Millan I, Diez S, et al. The long-term outcome of pituitary irradiation after unsuccessful transsphenoidal surgery in Cushing's disease. N Engl J Med 1997;336:172-7.

51. Stiefel P, Garcia-Morillo JS, Jimenez L, Pamies E, Miranda $\mathrm{ML}$, Carneado J, et al. Role of ketoconazole treatment in urinary-free cortisol-to-cortisone and tetrahydrocortisol-totetrahydrocortisone ratios in nonectopic Cushing's syndrome. Endocrine 2002;18:279-84.

52. Sonino N, Boscaro M, Paoletta A, Mantero F, Ziliotto D. Ketoconazole treatment in Cushing's syndrome: experience in 34 patients. Clin Endocrinol (Oxf) 1991;35:347-52.

53. Bertagna X, Bertagna C, Laudat MH, Husson J-M, Girard F, Luton JP. Pituitary-adrenal response to the antiglucocorticoid action of RU 486 in Cushing's syndrome. J Clin Endocrinol Metab 1986;63:639-43.

54. Nieman LK, Chrousos GP, Kellner Spitz IM, Nisula BC, Cutler GB, Merriam GR, et al. Successful treatment of Cushing's syndrome with the glucocorticoid antagonist RU-486. J Clin Endocrinol Metab 1985;61:536-50.

55. Niemann LK. Medical therapy of Cushing's disease. Pituitary 2002;5:77-82.

56. Sonino N, Boscaro M, Fallo F. Pharmacologic management of Cushing's syndrome: new targets for therapy. Treat Endocrinol 2005;4:87-94.

57. Shimon I, Melmed S. Management of pituitary tumors. Ann Intern Med 1998;129:472-83.

58. Miller JW, Crapo L. The medical treatment of Cushing's syndrome. Endocr Rev 1993;14:443-58.

59. Pivonello R, Ferone D, de Herder WW, Kros JM, De Caro ML, Arvigo $\mathrm{M}$, et al Dopamine receptor expression and function in corticotroph pituitary tumors. J Clin Endocrinol Metab 2004;89:2452-62.

60. Ambrosi B, Dall'Asta C, Cannavo S, Libe R, Vigo T, Epaminonda $P$, et al. Effects of chronic administration of PPAR-gamma ligand rosiglitazone in Cushing's disease. Eur J Endocrinol 2004; 151:173-8.

61. Giraldi FP, Scaroni C, Arvat E, Martin M, Giordano R, Albiger $\mathrm{N}$, et al. Effect of protracted treatment with rosiglitazone, a PPARgamma agonist in patients with Cushing's disease. Clin Endocrinol (Oxf) 2006;64:219-24.

62. Petrini L, Gasperi M, Pilosu R, Marcello A, Martino E. Longterm treatment of Nelson's syndrome by octreotide: a case report. J Endocrinol Invest 1994;17:135-9.

63. Plöckinger U, Rindi G, Arnold R, Eriksson B, Krenning EP, de Herder WW et al. European Neuroendocrine Tumour Society. Guidelines for the diagnosis and treatment of neuroendocrine gastrointestinal tumours. A consensus statement on behalf of the European Neuroendocrine Tumour Society (ENETS). Neuroendocrinology 2004;80:394-424.

64. Park S, Kamegai J, Kinema RD. Role of glucocorticoids in the regulation of pituitary somatostatin receptor subtype (sst1sst5) mRNA levels: evidence for direct and somatostatinmediated effects. Neuroendocrinology 2003;78:163-75.

65. Boerlin V, van der Hoek J, Beglinger Ch, Poon KW, Hartmann S, Dutreix C, et al. New insights on SOM230, a universal somatostatin receptor ligand. J Endocrinol Invest 2003;26:14-6.

66. Saveanu A, Gunz G, Guillen S, Dufour H, Culler MD, Jaquet P. Somatostatin and dopamine-somatostatin multiple ligands directed towards somatostatin and dopamine receptors in pituitary adenomas. Neuroendocrinology 2006;83:258-63.

67. Danila DC, Haidar JN, Zhang X, Katznelson L, Culler MD, Klibanski A. Somatostatin receptor-specific analogs: effects on cell proliferation and growth hormone secretion in human somatotroph tumors. J Clin Endocrinol Metab 2001; 86:2976-81.

68. Lacroix A, Hamet $P$, Boutin JM. Leuprolide acetate therapy in luteinizing hormone-dependent Cushing's syndrome. N Engl J Med 1999;341:1577-81. 
69. Reznik Y, Allali-Zerah V, Chayvialle JA, Leroyer R, Leymarie $P$ Travert G, et al. Food-dependent Cushing's syndrome mediated by aberrant adrenal sensitivity to gastric inhibitory polypeptide. N Engl J Med 1992;327:981-6.

70. Lebrethon MC, Avallet O, Archambault F, Combes J, Usdin TB, Narboni G, et al. Food-dependent Cushing's syndrome: characterization and functional role of gastric inhibitory polypeptide receptor in the adrenals of three patients. J Clin Endocrinol Metab 1998;83:4514-9.
Address for correspondence:

Franco Mantero

Endocrinology Division

Department of Medical and Surgical Sciences

University of Padua

Via Ospedale 105, 35128 Padova, Italy

Fax: 0039-049657391

E-mail: franco.mantero@unipd.it 